\title{
Some Streblidae and Nycteribiidae (Diptera: Hippoboscoidea) from Maracá Island, Roraima, Brazil
}

\author{
Gustavo Graciolli/+, Pedro Marcos Linardi"/ ++
}

Laboratório de Sistemática, Ecologia e Evolução, Departamento de Zoologia, Universidade Federal do Paraná, Caixa Postal 19020, 81531-990 Curitiba, PR, Brasil *Departamento de Parasitologia, ICB, Universidade Federal de Minas Gerais,

Belo Horizonte, MG, Brasil

Fourteen species in five genera of Streblidae and two species in two genera of Nycteribiidae, collected in Maracá Island, State of Roraima, Brazil are presented with comments on bat hosts and geographical distribution. A total of 42 specimens of Diptera and 17 bats were captured from 1987 to 1988, integrating the "Maracá Project". All species of ectoparasites represent new geographic records for Roraima.

Key words: Streblidae - Nycteribiidae - ectoparasites - bats - Roraima - Brazil

During 1987-1988 a floristic, faunistic and geologic survey called "Maracá Project" was carried out in Maracá Island, State of Roraima, Brazil. Sponsors of this project were Instituto de Pesquisas da Amazônia (Inpa), exSecretaria Especial do Meio Ambiente (Sema) and the Royal Geographic Society. Several Brazilian and foreign researchers developed activitities in this project. Partial results about others taxa of insects were previously published in a special volume of Acta Amazônica, 1991.

In this paper, we examined 42 specimens of batflies (Diptera: Streblidae and Nycteribiidae) from 17 bats (Chiroptera) captured during this project by other teams. The batflies are deposited at the Setor de Ectoparasitos, Museu de Zoologia, Universidade de São Paulo (MZSP).

The collected material yielded 14 species (one of them separated in two subspecies) in five genera of Streblidae and two species in a single genus of Nycteribiidae. All of them constitute new records for the State of Roraima.

A list of the batflies found is given below. A brief report, including examined material and distributional notes, is included for each species or subspecies.

\section{STREBLIDAE}

Trichobius caecus Edwards, 1918

Specimens examined: 2 males and 1 female, undetermined bat, no date.

Remarks: T. caecus was recorded in Brazil, in old "State of Mato Grosso" on undetermined host (Pessôa \& Guimarães 1940). Afterwards, it was recorded in Trinidad, Venezuela, and French Guiane (Guerrero 1997). T. caecus occurs on momoorpid bats of the genus Pteronotus Gray.

Trichobius joblingi Wenzel, 1966

Specimens examined: 4 males on Phyllostomus elongatus

Contribution \#1307 of Departamento de Zoologia, Universidade Federal do Paraná.

${ }^{+}$Corresponding author. Fax: +55-41-226-20422. E-mail: mingau@bio.ufpr.br

${ }^{++}$Research fellow of $\mathrm{CNPq}$

Received 16 April 2001

Accepted 10 September 2001
(E. Geoffroy), 21/XI/1987; 4 females on Carollia perspicillata (L.), 05/XII/1987; 1 male on C. perspicillata, 09/XII/1987; 2 males on $C$. perspicillata, 18/XII/1987; 1 male on P. elongatus, 19/XII/1987.

Remarks: this is the most abundant species of streblid batfly found in the Neotropical Region, and the main parasite of C. perspicillata (Guerrero 1995a). In the Brazilian Amazon, T. joblingi has been recorded: in the State of Rondônia on C. perspicillata (Guerrero 1995a); in the State of Pará on C. perspicillata, Artibeus anderseni Osgood and Platyrrhinus helleri (Peters) (Guerrero 1997).

Trichobius dugesioides dugesioides Wenzel, 1966 Specimens examined: 1 male and 3 females on Trachops cirrhosus (Spix), 22/XII/1987.

Remarks: T. $d$. dugesioides was recorded on T. cirrhosus and Tonatia bidens (Spix) from Pará (Guerrero 1997).

Trichobius dugesioides phyllostomus Guerrero, 1998 Specimens examined: 1 male and 1 female on Phyllostomus elongatus, 19/XII/1987.

Remarks: it represents a new record for Brazil. Previously, T. dugesioides phyllostomus was collected on Phyllostomus elongatus from Venezuela (Guerrero 1998).

Trichobius flagellatus Wenzel, 1976

Specimens examined: 1 male and 2 females on Lonchorhina aurita Tomes, 15/XII/1987.

Remarks: T. flagellatus was previously recorded in Venezuela on L. aurita and L. orinocensis Linares \& Ojasti (Wenzel 1976, Guerrero 1995a), and in Distrito Federal, Brazil on L. aurita (Coimbra Jr. et al. 1984).

Trichobius parasiticus Gervais, 1844

Specimens examined: 2 males and 1 female on Desmodus rotundus (E. Geoffroy), 10/XII/1987.

Remarks: this is a characteristic ectoparasite of the bloodfeeding bat $D$. rotundus, in all geographic distribution of its host, except for Southern Brazil, where it seems to be displaced by Trichobius furmani Wenzel.

Trichobius uniformis Curran, 1935

Specimens examined: 1 female on Carollia perspicillata, 15/XII/1987.

Remarks: T. uniformis is usually found on phyllostomid bats of the genus Glossophaga Geoffroy (Guerrero 1994a). Guimarães (1937) reported T. uniformis in the States of 
Pernambuco and Minas Gerais, but the host species were not identified.

Speiseria ambigua Kessel, 1925

Specimens examined: 2 males and 2 females on Carollia perspicillata, 05/XII/1987; 1 male on C. perspicillata, 22/ XII/1987.

Remarks: species mainly found on $C$. perspicillata. Guerrero (1997) recorded S. ambigua on T. cirrhosus from Belém, Pará.

Paratrichobius dunni (Curran, 1935)

Specimen examined: 1 male on Uroderma bilobatum Peters, no date.

Remarks: this ectoparasite is normally found parasitizing phyllostomid bats of the genus Uroderma Peters. Guerrero (1994b) recorded $P$. dunni on $U$. bilobatum from Rondônia.

Aspidoptera falcata Wenzel, 1976

Specimens examined: 1 male on Sturnira tildae de la Torre, 21/XII/1987.

Remarks: Guerrero (1997) recorded A. falcata on S. tildae from Pará.

Aspidoptera phyllostomatis (Perty, 1833)

Specimens examined: 1 male on Artibeus $c f$. jamaicensis Leach, 22/XII/1987.

Remarks: this species is often found on bats of the genus Artibeus Leach (Phyllostomidae). A. phyllostomatis was previously recorded by Guerrero (1995b) on Artibeus lituratus (Olfers) from Rondônia.

Strebla sp.

Specimens examined: 1 female, undetermined host, no date. Remarks: although the species has not been identified, it is very similar to Strebla alvarezi Wenzel and S. cormurae Wenzel.

\section{Strebla consocia Wenzel, 1966}

Specimens examined: 1 female on Phyllostomus elongatus, 19/XII/1987.

Remarks: this is a characteristic ectoparasite of $P$. hastatus (Pallas) (Phyllostomidae), but it can also be often found on P. elongatus (Guerrero 1996). In Brazil, it was already recorded on P. hastatus from Pará (Guerrero 1997).

Strebla altmani Wenzel, 1966

Specimens examined: 1 male on Lonchorhina aurita, 15/ XII/1987.

Remarks: this species is often found on phyllostomid bats of the genus Lonchorhina Tomes (Guerrero 1996). In Brazil, Coimbra Jr. et al. (1984) recorded it on L. aurita from Distrito Federal.

Strebla wiedemanni Kolenati, 1856

Specimens examined: 1 male on Desmodus rotundus, 10/ XII/1987.

Remarks: this is a characteristic ectoparasite of $D$. rotundus, and was recorded in Pará on this same host (Guerrero 1996).

\section{NYCTERIBIIDAE}

\section{Basilia sp.}

Specimens examined: 1 male, undetermined host, no date; 2 males on Myotis cf. albescens E. Geoffroy, 06/XII/1987. Remarks: as emphasized by Guimarães and D'Andretta (1956), the most important character to identify the American species of Basilia Ribeiro are present in females. Hence, it was not possible to identify the males of this species.
Basilia dunni Curran, 1935

Specimens examined: 2 females on Myotis sp., 21/XII/1987. Remarks: this species belongs to speiseri group of Theodor (1967). It represents a new record for Brazil. Previously, the records of this species were restricted to Panamá and Venezuela, on Myotis nigricans (Schinz) and Myotis albescens Geoffroy (Guimarães 1966).

Basilia ferrisi Schuurmans-Stekhoven Jr., 1931

Specimens examined: 1 female on Myotis cf. nigricans (Schinz), 02/II/1988.

Remarks: this species belongs to speiseri group of Theodor (1967). It represents a new record for Brazil. Previously, it was found in Costa Rica, Colômbia, Guatemala, Guiana, Peru, and Venezuela. Basilia ferrisi occurs on Myotis albescens Geoffroy, Myotis nigricans, and Myotis riparius Handley (Guimarães 1972).

Discussion - Prior to this study, 37 species in 14 genera of Streblidae and two species in two genera of Nycteribiidae had been recorded in the Brazilian Amazon Region. Adding our new species and subspecies records (Trichobius caecus, T. dugesioides phyllostomus, $T$. flagellatus, T. uniformis, Strebla altmani, S. consocia, Basilia dunni, and B. ferrisi), the number of batflies species increases to 43 in this area. However, it is important to emphasize that the number of species recorded in the Brazilian Amazon Region is far below than that of neighbouring countries such as Colombia, which has 54 species of Streblidae and 7 of Nycteribiidae; Venezuela, with 121 and 12 species, respectively; and Peru, with 59 and eight species, respectively (Guerrero 1997). This is probably due to insuficient collecting at the Region, meaning is that more field effort is needed to better understand the distribution and relationship of parasite batflies and their bat hosts.

\section{ACKNOWLEDGMENTS}

To Dr Mauricio O Moura and MSc Rodrigo Filipak Torres for helpful comments on the manuscript.

\section{REFERENCES}

Coimbra Jr. CEA, Guimarães LR, Mello DA 1984. Ocorrência de Streblidae (Diptera: Pupipara) em morcegos capturados em regiões de cerrado do Brasil Central. Revta Bras Ent 28: 547-550.

Guerrero R 1994a. Catalogo de los Streblidae (Diptera: Pupipara) parasitos de murcielagos (Mammalia: Chiroptera) del Nuevo Mundo. II. Los grupos: pallidus, caecus, major, uniformis y longipes del genero Trichobius Gervais, 1844. Acta Biol Venez. 15: $1-18$.

Guerrero R 1994b. Catalogo de los Streblidae (Diptera: Pupipara) parasitos de murcielagos (Mammalia: Chiroptera) del Nuevo Mundo. IV. Trichobiinae com alas desarrolladas. Bol Entomol Venez 9: 161-192.

Guerrero R 1995a. Catalogo de los Streblidae (Diptera: Pupipara) parasitos de murcielagos (Mammalia: Chiroptera) del Nuevo Mundo. III. Los grupos: dugesii, dunni y phyllostomae del genero Trichobius Gervais, 1844. Acta Biol Venez 15: 1-27.

Guerrero R 1995b. Catalogo de los Streblidae (Diptera: Pupipara) parasitos de murcielagos (Mammalia: Chiroptera) del Nuevo Mundo. V. Trichobiinae con alas reducidas o ausentes y miscelaneos. Bol Entomol Venez, 10: 135-160.

Guerrero R 1996. Catalogo de los Streblidae (Diptera: Pupipara) parasitos de murcielagos (Mammalia: Chiroptera) del Nuevo Mundo. VI. Streblinae. Acta Biol Venez 16: 1-26.

Guerrero R 1997. Catalogo de los Streblidae (Diptera: Pupipara) parasitos de murcielagos (Mammalia: Chiroptera) del Nuevo Mundo. VII. Lista de especies, hospedadores y paises. Acta 
Biol Venez, 17: 9-24.

Guerrero R 1998. Notes on batflies (Diptera, Streblidae). I. The genus Trichobius, with description of two new species and new subspecies from Venezuela. Acta Parasitol 43: 86-93.

Guimarães LR 1937. Sobre as especies sul americanas do genero Trichobius (Diptera-Streblidae). Rev Museu Paulista 23: 653666.

Guimarães LR 1966. Nycteribiid batflies from Panama (Díptera: Nycteribiidae). In RL Wenzel, VJ Tipton (eds), Ectoparasites of Panama, Field Mus Nat Hist, Chicago, p. 393-404.

Guimarães LR 1972. Venezuelan nycteribiid batflies (Diptera: Nycteribiidae). Brigham Young Univ Sci Bull, Biol Ser 17: 111.
Guimarães LR, D’Andretta MAV 1956. Sinopse dos Nycteribiidae (Diptera) do Novo Mundo. Arq Zool Estado de São Paulo 10: 1-184.

Pessôa SB, Guimarães LR 1940. Nota sobre streblídeos (Diptera) de morcegos de Mato-Grosso, Brasil. Archos Inst Biol 11: 421-426.

Theodor O 1967. An Illustrated Catalogue of the Rothschld Collection of Nycteribiidae (Diptera) in the British Museum (Natural History) with Keys and Short Descriptions for the Identification of Subfamilies, Genera, Species, and Subspecies, British Museum (Natural History), London, number 655, $506 \mathrm{pp}$.

Wenzel RL 1976. The streblid batflies of Venezuela (Diptera: Streblidae). Brigham Young Univ Sci Bull Biol Ser 20: 1-177. 
142 Streblidae and Nycteribiidae from Brazil $\bullet$ G Graciolli , PM Linardi 